\title{
CORRESPONDENCE
}

\section{To the Editor of THE ClassiCal Review.}

SIR,-Having had occasion to investigate the mythological or religious character of Harpocrates, I have found certain defects in that most useful book of reference, Smith's Dictionary of Greek and Roman Biography and Mythology, to which I would call attention. Under the word Harpocrates the reader is merely referred to Horus. Horus is said to have been compared with the Greek Apollo (so far good), and to be identified with Harpocrates, the last-born and weakly son of Osiris.

This is what is wrong. The genealogy of Horus is to be found (as Smith says) in Herodotus, Diodorus, and Plutarch, De Iside et Osiride. Neither Herodotus nor Diodorus mention Harpocrates. Herodotus no doubt makes Horus a child of Isis, and apparently of Osiris (ii. 156). Plutarch in one part of the De Iside and Osiride also makes Horus a child, the eldest child, of Isis and Osiris. In another part he speaks of Horus as child of Rhea and

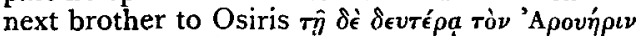

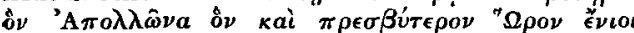

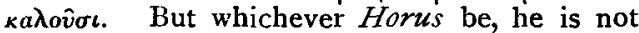
Harpocrates, who, as Smith says, was the lastborn and weakly son of Osiris, posthumous and premature, $\dot{\eta} \lambda$ cró $\mu \eta \nu o \nu$.

There are mistakes in the references in the same article which I may as well correct, as one gave me and others much trouble. Artemidorus Oneirocritica is ii. 39 , not ii. 36 . Macrobius Saturnal. is i. 21, not i. 23. Smith's Classical Dictionary, ed. G. E. Marindin, I899, repeats the mistake Horus $=$ Harpocrates, and adds a reference to Pliny, also not quite correct. It should be Hist. Nat. lib. 33, c. I 2, not c. 4I.

I should be glad if any of your readers could furnish me with any other mention of Harpocrates in Greek or Roman literature. The two Smith's Dictionaries give, as I have said, Varro, Pliny, Plutarch, and Artemidorus, and add Ov. Metam. ix. 69 I, Ausonius, Epist. ad Paulin. xxv. 27, two quotations where he is probably mentioned by character, though not by name. I would add Catullus, lxxiv. 4 (name) and S. Augustine, De Civitate Dei, lib. xviii. 5 (character), and, if we can reckon it, the late epigram, 'Est Rosa flos Veneris,' etc., in Lemaire, Poet. Lat. Min., vol. vii., p. I25.

I am anxious to make out whether Harpocrates was really regarded as a god, at any rate as an executive god, having power to create silence $\left(\dot{\epsilon}^{\prime} \chi \mu \nu \theta^{\prime} a\right)$ or punish for breach of it, or merely as an emblem or personification.

I have not been able to refer to two quotations in the larger Smith-Porphyr. ap. Eusebium Praep. Evang. v. 10 and Iamblich. de Myster. vii. 2-and do not know whether they refer to Harpocrates or to Horus.

Artemidorus no doubt classes Harpocrates with Serapis, Isis, and Anubis as Akós, and perhaps Ovid has the same idea. But Plutarch evidently did not regard him as a god, and I think the other writers whom I have mentioned treat him merely as a personification.

\section{Walter G. F. Phillimore.}

\section{The Coppice, Henley-on-Thames, August 4, I9II.}

,

\section{To the Editor of THE CLAssical Review.}

SIR,-In Mr. Bailey's excellent review of two books upon the Bacchae of Euripides, some sentences occur which appear to say that I take 'the traditional view' of the play; the said view being 'that it was written to show the divine power of Dionysus and the futility of human opposition.'

The notes to my translation and the few sentences on the play in my Greek Literature show that I am vehemently opposed to any such view, and I think it very likely that Mr. Bailey did not really mean to attribute it to me. Nor, of course, does Dr. Verrall. But various writers have recently done so, and you will perhaps allow me to correct them. I have not the books with me at present, but I certainly remember saying that Dionysus at the end was shown as a devil rather than a god. In general I agree almost exactly with Mr. Bailey's own view : 'Here is the ancient legend as it must have happened if it be true, and here are the results of the Bacchic enthusiasm.'

One might almost make a motto to the play out of Caliban's tragic words :

'What a thrice-double ass

Was I, to take this drunkard for a god!'

remembering always that the Bacchanals of Euripides are drunk not with wine but with beauty and emotion. Where I have differed from some 'tendenziös' explanations of the play is in pointing out that in the Bacchae this drunkenness, this ecstasy, is so wonderfully and even lovingly expressed that in the end the fascination of it almost balances the horror. It is a matter of proportion. If the Bacchae were merely, or mainly, a criticism or a tract, if the poet's main motive were anti-bacchic propaganda, this balance would surely be utterly different. Of course, the poet had his beliefs, or at any rate his disbeliefs, about Dionysus; but surely in writing this play it was the subject that fascinated him, not the opportunity of expressing any particular theory about the subject. The point is of cardinal importance to criticism. He certainly did not write all those choruses merely because he disapproved of such things, and wanted to show how wicked they were.

I will not dwell on the two or three points 